(c) American Dairy Science Association, 2003.

\title{
Increased Nuclear Factor $\kappa$ B Activity in Milk Cells of Mastitis-Affected Cows
}

\author{
D. Boulanger, ${ }^{\star}$ F. Bureau, ${ }^{\star}$ D. Mélotte, ${ }^{\star}$ J. Mainil,† and P. Lekeux \\ *Department of Physiology and \\ †Department of Microbiology, Faculty of Veterinary Medicine, \\ University of Liège, Boulevard de Colonster 20, B-4000 Liège, Belgium
}

\section{ABSTRACT}

Bacterial mastitis is accompanied by a drastic increase in milk somatic cell count (SCC), with neutrophils being the predominant cell type found in the infected quarters. Accumulation and activation of neutrophils at the site of infection require local expression of many inflammatory genes encoding adhesion molecules, chemokines and cytokines. Most of the inflammatory genes contain binding sites for the nuclear factor $\kappa \mathrm{B}(\mathrm{NF}-\kappa \mathrm{B})$ within their promoter and therefore partly depend on NF- $\kappa \mathrm{B}$ for their expression. We thus hypothesized that an increase in $\mathrm{NF}-\kappa \mathrm{B}$ activity in the mammary gland could contribute to development of the neutrophilic inflammation that characterizes mastitis. In an attempt to verify this hypothesis, we first assessed milk cells from healthy and acute and chronic mastitis-affected cows for NF- $\kappa$ B activity using electrophoretic mobility shift assays. We next studied the relationships between the intensity of NF$\kappa \mathrm{B}$ activity in these cells and the degree of udder inflammation. Active NF- $\kappa \mathrm{B}$ complexes were undetectable in milk cells from healthy cows, whereas high levels of $\mathrm{NF}-\kappa \mathrm{B}$ activity were always found in cells from cows with acute mastitis. In milk cells obtained from chronic mastitis-affected cows, NF- $\kappa$ B activity varied from low to high. Finally, the level of NF- $\kappa \mathrm{B}$ activity measured in milk cells from chronic mastitis-affected cows was not correlated to SCC or to the proportion of neutrophils present in milk samples, but was highly correlated with the expression level of interleukin-8 and granulocyte/ macrophage colony-stimulating factor, two NF- $\kappa$ B-dependent cytokines crucially involved in initiation and perpetuation of neutrophilic inflammation. These results suggest that $\mathrm{NF}-\kappa \mathrm{B}$ might play a role in mastitis pathogenesis.

(Key words: dairy cow, mastitis, nuclear factor $\kappa \mathrm{B}$ )

Abbreviation key: DFP = diisopropyl fluorophosphate, DTT $=$ dithiothreitol, EGTA = ethylene glycol-bis $[\beta$-ami-

Received August 9, 2002.

Accepted October 6, 2002.

Corresponding author: Delphine Boulanger; e-mail: delphine. boulanger@ulg.ac.be. noethyl ether]-N, N, N'N'-tetraacetic acid, EMSA = electrophoretic mobility shift assays, GM-CSF = granulocyte/macrophage colony-stimulating factor, ICAM-1 = intercellular adhesion molecule-1, IL = interleukin, NF$\kappa \mathbf{B}=$ nuclear factor $\kappa \mathrm{B}, \mathbf{T N F}=$ tumor necrosis factor, VCAM-1 = vascular cell adhesion molecule-1.

\section{INTRODUCTION}

Mastitis is one of the most costly diseases in dairy herds. Costs mainly arise from decreased milk production and quality, therapeutic interventions, loss of antibiotic-contaminated milk, and extra labor (Degraves and Fetrow, 1993). Mastitis, defined as an inflammatory condition of the mammary gland, is usually caused by pathogenic bacteria. The most common pathogens that provoke mastitis include Staphylococcus aureus, Streptococcus agalactiae, Streptococcus dysgalactiae, Streptococcus uberis, Arcanobacterium pyogenes and coliforms (Watts, 1988). Acute mastitis is an abrupt and short-lived inflammation of the udder associated with clinical signs. Conversely, chronic mastitis is a moderate and persistent inflammation of the mammary gland that is usually not accompanied by clinical signs (Jain, 1979).

Acute and chronic mastitis are associated with a drastic increase in milk SCC, with neutrophils being the predominant cell type found in the infected mammary quarter (Shalm and Lasmanis, 1968; Paape et al., 1979; Burvenich et al., 1994). Neutrophils are potent inflammatory cells that engulf and kill bacterial pathogens. The accumulation and the activation of neutrophils at the site of infection require local expression of many inflammatory proteins, such as: 1) adhesion factors, including intercellular adhesion molecule-1 (ICAM-1) and vascular cell adhesion molecule-1 (VCAM-1), which play a cardinal role in neutrophil margination, diapedesis and transepithelial migration; 2) chemokines, such as interleukin (IL)-8, which is potently chemotactic for neutrophils; and 3) cytokines, such as IL- $1 \beta$ and tumor necrosis factor (TNF)- $\alpha$, which activate neutrophils, and granulocyte/macrophage colony-stimulating factor (GMCSF), which increases neutrophil survival (Coxon et al., 1999). Increased TNF- $\alpha$, IL- $1 \beta$, and IL- 8 concentrations 
in milk from mastitis-affected cows have been reported, emphasizing the potential role of these proteins in neutrophilic inflammation of the mammary gland (Shuster et al., 1993; Barber and Yang, 1998; Riollet et al., 2001).

Most of the genes encoding inflammatory proteins involved in neutrophil migration and activation have been shown to contain $\kappa \mathrm{B}$ sites for the nuclear factor $\kappa \mathrm{B}$ (NF$\boldsymbol{\kappa} \mathbf{B})$ within their promoter and therefore to partly depend on $\mathrm{NF}-\kappa \mathrm{B}$ for their expression (Pahl, 1999), suggesting that this transcription factor might play a role in the pathophysiology of mastitis. The NF- $\kappa \mathrm{B}$ family is composed of five structurally-related DNA-binding proteins, called p50, p52, p65/RelA, c-Rel/Rel, and RelB (Siebenlist et al., 1994). The most common form of NF- $\kappa \mathrm{B}$ is a heterodimer composed of p50 and p65 subunits, although the different family members can associate in various homoor heterodimers through a highly conserved $N$-terminal sequence, called the Rel homology domain. In most cell types, inactive NF- $\kappa \mathrm{B}$ complexes are associated with inhibitory proteins of the $\mathrm{I} \kappa \mathrm{B}$ family, which sequester NF$\kappa \mathrm{B}$ in the cytoplasm. The members of the $\mathrm{I} \kappa \mathrm{B}$ family are $\mathrm{I} \kappa \mathrm{B}-\alpha, \mathrm{I} \kappa \mathrm{B}-\beta, \mathrm{I} \kappa \mathrm{B}-\varepsilon, \mathrm{p} 100, \mathrm{p} 105$, and $\mathrm{Bcl}-3$, where the most common $\mathrm{I} \kappa \mathrm{B}$ protein is $\mathrm{I} \kappa \mathrm{B}-\alpha$ (Siebenlist et al., 1994; Whiteside et al., 1997). Following various stimuli, such as viruses, bacteria, prooxidants, and proinflammatory cytokines, $\mathrm{I} \kappa \mathrm{B}$ proteins are first phosphorylated, ubiquitinated and then rapidly degraded by the proteasome, allowing NF- $\kappa \mathrm{B}$ nuclear translocation and transcriptional initiation of NF- $\kappa \mathrm{B}$-dependent genes (Beg et al., 1993).

In the present study, we hypothesized that an increase in NF- $\kappa \mathrm{B}$ activity in the udder could be involved in the pathophysiology of mastitis. In an attempt to verify this hypothesis, we first measured the level of NF- $\kappa$ B activity in milk cells from healthy and acute and chronic mastitis-affected cows. Second, we characterized the active $\mathrm{NF}-\kappa \mathrm{B}$ complexes found in these cells. Finally, we studied the relationships between the level of NF- $\kappa \mathrm{B}$ activity and the degree of inflammation in the mammary gland.

\section{MATERIALS AND METHODS}

\section{Animals}

Sixteen healthy, 6 acute and 20 chronic mastitis-affected Holstein-Friesian cows were used in this study. Healthy cows had low SCC $\left(<10^{5}\right.$ cells $\left./ \mathrm{ml}\right)$ and were free of any clinical sign of mastitis. Acute mastitis-affected cows had high SCC $\left(>10^{7}\right.$ cells $\left./ \mathrm{ml}\right)$ and exhibited clinical signs of illness. Neither healthy nor acute mastitis-affected cows had earlier record of udder disease, as measured by clinical symptoms and monthly SCC recordings. Chronic mastitis-affected cows had persistently increased SCC $\left(>4 \times 10^{5}\right.$ cells $\left./ \mathrm{ml}\right)$, as determined by monthly SCC measurements, but were devoid of any clinical sign of the disease. All the cows were between 2 and $7 \mathrm{yr}$ old, had a lactation number ranging from 1 to 5 and were lactating for 1 to 6 mo. Experimental cows did not receive any treatment during the month preceding the experiments.

\section{Sterile Milk Sampling}

Milk was collected using a sterile teat cannula infusion apparatus as previously described by Vangroenweghe et al. (2001). This apparatus consisted of a sterile and pyrogen-free cannula inserted into the teat canal and connected to the free end of an infusion set attached to a $2000 \mathrm{ml}$ sterile collection bag (Urine drainage bag, Urias, Denmark). Milk samples were taken from one quarter. Before sampling, the quarter was thoroughly disinfected with a solution containing $70 \%$ alcohol and $30 \%$ chlorohexidine (Hibitex, Mallinckrodt Veterinary, Belgium).

\section{Microbiological Analysis}

Immediately after milk sampling, an aliquot of $50 \mu \mathrm{l}$ was inoculated for bacterial counts and identification onto Columbia agar with 5\% sheep blood (Becton Dickinson, Belgium) and Gassner agar (Oxoid, Belgium), which is selective for Enterobacteriaceae and a few other bacterial genera. The plates were incubated overnight at $37^{\circ} \mathrm{C}$; negative plates were incubated for another $24 \mathrm{~h}$. Bacteria were identified using classical procedure and appropriate API Sugar sets (BioMérieux, France). Isolation of $\geq 100 \mathrm{cfu} / \mathrm{ml}$ of mastitis pathogens was considered significant. If three or more bacterial species grew from any sample, this sample was considered contaminated and was excluded from the study.

\section{SCC}

Immediately after milk collection, $50 \mathrm{ml}$ of each milk sample was shipped to a specialized laboratory (Laboratory of the Milk Committee, Battice, Belgium), where an SCC was performed following standard procedure.

\section{Isolation of Milk Cells}

Milk samples were first centrifuged $(300 \times g)$ for $30 \mathrm{~min}$ at $4^{\circ} \mathrm{C}$. Pellets were then washed in PBS and centrifuged $(300 \times g)$ for another $30 \mathrm{~min}$ at $4^{\circ} \mathrm{C}$. The pelleted cells were finally resuspended in $1 \mathrm{ml}$ of PBS before protein extraction. Cell differentials were performed on cytospin preparations stained with Diff-Quick (Dade Behring, Dudingen, Germany).

\section{Protein Extraction}

Protein extracts were prepared as previously described by Al Shami et al. (1998). Isolated milk cells 
were centrifuged for $10 \mathrm{~min}$ at $300 \mathrm{~g}$ and the pellet was resuspended in $600 \mu \mathrm{l}$ lysis buffer $(0.1 \%$ nonidet $\mathrm{P}-40$; $10 \mathrm{~m} M$ Tris $\mathrm{HCl}, \mathrm{pH} 7.4 ; 10 \mathrm{~m} M \mathrm{NaCl} ; 3 \mathrm{~m} M \mathrm{MgCl}_{2}$; $1 \mathrm{~m} M$ EDTA; $2 \mathrm{~m} M$ orthovanadate; $1 \mathrm{~m} M$ diisopropyl fluorophosphates (DFP); $10 \mu \mathrm{g} / \mathrm{ml}$ leupeptin; $10 \mu \mathrm{g} / \mathrm{ml}$ aprotinin). The cells were vortexed $15 \mathrm{~s}$, kept on ice for $5 \mathrm{~min}$, and centrifuged for $10 \mathrm{~min}$ at $300 \mathrm{~g}$. The resulting pellet was resuspended in a $\mathrm{KCl}$ buffer $(10 \mathrm{~m} M$ Hepes, $\mathrm{pH}$ 7.4; $400 \mathrm{mM} \mathrm{KCl} ; 10 \%$ Glycerol; $2 \mathrm{~m} M$ EDTA; 1 $\mathrm{m} M$ Ethylene glycol-bis[ $\beta$-aminoethyl ether]-N, N, $\mathrm{N}^{\prime} \mathrm{N}^{\prime}$ tetraacetic acid (EGTA); $1 \%$ nonidet P-40, $1 \mathrm{~m} M$ dithiothreitol (DTT); $2 \mathrm{~m} M$ orthovanadate; $10 \mu \mathrm{g} / \mathrm{ml}$ leupeptin; $10 \mu \mathrm{g} / \mathrm{ml}$ aprotinin; $1 \mathrm{~m} M$ DFP) and kept at $4^{\circ} \mathrm{C}$ for $10 \mathrm{~min}$ before centrifugation for $15 \mathrm{~min}$ at $12,000 \times$ $g$. The supernatant was diluted three times and stored at $-80^{\circ} \mathrm{C}$ until use. Protein amounts were quantified using the Biorad Protein Assay (Bradford method; Biorad, Nazareth, Belgium).

\section{Nuclear Factor- $\kappa$ B Electrophoretic Mobility Shift Assays (EMSA)}

Binding reactions were performed for $30 \mathrm{~min}$ at room temperature with $5 \mu \mathrm{g}$ of total protein extracts in 20 $\mathrm{m} M$ Hepes (pH 7.9), $10 \mathrm{~m} M \mathrm{KCl}, 0.2 \mathrm{~m} M$ EDTA, $20 \%$ $(\mathrm{v} / \mathrm{v})$ glycerol, $1 \%(\mathrm{w} / \mathrm{v})$ acetylated bovine serum albumin, $3 \mu \mathrm{g}$ of poly (dI-dC) (Amersham Pharmacia Biotech, Aylesbury, U.K.), $1 \mathrm{~m} M$ DTT, $1 \mathrm{~m} M$ Phenylmethylsulfonyl fluoride, and 100,000 cpm of ${ }^{32}$ P-labeled doublestranded oligonucleotide probes. Probes were prepared by annealing the appropriate single-stranded oligonucleotides (Eurogentech, Liège, Belgium) at $65^{\circ} \mathrm{C}$ for $10 \mathrm{~min}$ in $10 \mathrm{~m} M$ Tris, $1 \mathrm{~m} M$ EDTA, and $10 \mathrm{~m} M \mathrm{NaCl}$, followed by slow cooling to room temperature. The probes were labeled by end-filling with the Klenow fragment of $E$. coli DNA polymerase I (Roche, Mannheim, Germany), with $\left[{ }^{32} \mathrm{P}\right] \mathrm{dATP}$ and $\left[{ }^{32} \mathrm{P}\right] \mathrm{dCTP}$ (Dupont-New England Nuclear, Les Ulis, Fance). Labeled probes were purified by spin chromatography on Sephadex G-25 columns (Roche). DNA-protein complexes were separated from unbound probe on $4 \%$ native polyacrylamide gels at 150 $\mathrm{V}$ in $0.25 M$ Tris, $0.25 M$ sodium borate, and $0.5 \mathrm{mM}$ EDTA, pH 8.0. Gels were vacuum-dried and exposed to Fuji x-ray film (Tokyo) at $-80^{\circ} \mathrm{C}$ for $12 \mathrm{~h}$. The amount of specific complexes was determined by photodensitometry of the autoradiography (Gel Doc 2000; Bio-Rad, Hercules, CA). To confirm specificity, competition assays were performed with a 50 -fold excess of unlabeled wildtype and mutated probes. For supershift experiments, $1.5 \mu \mathrm{l}$ of each antibody was incubated with the extracts 30 min before addition of the radiolabeled probe. The sequences of the oligonucleotides used in this work were as follows: wild-type palindromic $\kappa \mathrm{B}$ probe (also referred to as consensual $\kappa$ B probe), $5^{\prime}$-TTG GCA ACG GCA GGG
GAA TTC CCC TCT CCT TAG GTT-3'; and mutated palindromic $\kappa$ B probe, 5'-TTG GCA ACG GCA GAT CTA TTC CCC TCT CCT TAG GTT- 3 . The NF- $\kappa$ B activity was assessed by photodensitometry of the specific bands (Gel Doc 2000).

\section{Immunoblots}

Protein extracts $(10 \mu \mathrm{g})$ were added to a loading buffer (10 mM Tris-HCl (pH 6.8), 1\% (w/v) SDS, 25\% (v/v) glycerol, $0.1 \mathrm{mM}$ 2-mercapto-ethanol, and $0.03 \%$ (w/v) bromophenol blue), boiled, and run on a $10 \%$ SDS-polyacrylamide gel electrophoresis gel. After electrotransfer to polyvinylidene difluoride membranes (Roche Diagnostics, Brussels, Belgium) and blocking overnight at $4^{\circ} \mathrm{C}$ with $20 \mathrm{~m} M$ Tris ( $\mathrm{pH} 7.5), 500 \mathrm{~m} M \mathrm{NaCl}, 0.2(\mathrm{v} / \mathrm{v})$ Tween 20 (Tris-HCl/ Tween), and 5\% (w/v) dry milk, the membranes were incubated for $1 \mathrm{~h}$ with primary antibodies directed to IL-8 or GM-CSF (1/200 dilution), washed, and then incubated for $45 \mathrm{~min}$ with peroxydase-conjugated rabbit anti-mouse IgG (1/1000 dilution). Resulting reactions were revealed with the enhanced chemiluminescence detection method (ECL kit; Amersham Pharmacia Biotech). The expression levels of IL-8 and GM-CSF were assessed by photodensitometry of the specific bands (Gel Doc 2000). Equal loading of proteins on the gels was confirmed by performing silver stains (data not shown).

\section{Anti-NF- $\kappa$ B, Anti-IL-8, and Anti-GM-CSF Antibodies}

The anti-NF- $\kappa$ B antibodies used were: 1 ) a rabbit antibody recognizing the nuclear localization sequence of p50 (Santa Cruz Biotechnology, Inc., Santa Cruz, California); 2) a rabbit antibody directed to a $\mathrm{NH}_{2}$-terminal peptide of p65 (Santa Cruz Biotechnology, Inc.); 3) a rabbit antibody directed against a conserved epitope of p52 (Santa Cruz Biotechnology, Inc.); 4) a rabbit antibody recognizing the $\mathrm{NH}_{2}$-terminal domain of c-Rel (Santa Cruz Biotechnology, Inc.); 5) a rabbit antibody directed to the $\mathrm{COOH}$-terminal domain of RelB (Santa Cruz Biotechnology, Inc.). The anti-IL-8 antibody used was a mouse monoclonal antibody recognizing the ovine IL-8 and cross-reacting with bovine IL-8 (Serotec, Ltd., Oxford, United Kingdom). The anti-GM-CSF antibody used was a mouse monoclonal antibody recognizing bovine GMCSF (Serotec, Ltd.).

\section{Statistical Analysis}

Data are presented as median \pm interquartile ranges. The differences between median values were estimated by the use of a Student's $t$ test for unpaired data. Linear associations between variables were assessed by the use of standard least-square linear regressions. Correlation 
Table 1. Cellular characteristics of milk recovered from healthy, and acute and chronic mastitis-affected Holstein-Friesian cows.

\begin{tabular}{llcc}
\hline & $\begin{array}{l}\text { Healthy } \\
(\mathrm{n}=16)\end{array}$ & $\begin{array}{l}\text { Acute } \\
(\mathrm{n}=6)\end{array}$ & $\begin{array}{c}\text { Chronic } \\
(\mathrm{n}=20)\end{array}$ \\
SCC, $\times 1000 / \mathrm{ml}$ & $24.0 \pm 30.5$ & $>9999^{* * *}$ & $1001 \pm 1206.1^{* * *}$ \\
Macrophages, \% & $55.8 \pm 21.575$ & $1.1 \pm 0.7^{* * *}$ & $1.9 \pm 0.35^{* * * *}$ \\
Lymphocytes, \% & $13.0 \pm 3.175$ & $8.1 \pm 6.7^{* * *}$ & $12.7 \pm 10.3$ \\
Neutrophils, \% & $8.0 \pm 5.225$ & $90.8 \pm 6.5^{* * *}$ & $82.95 \pm 18.8^{* * *}$ \\
\hline
\end{tabular}

Results are expressed as median \pm interquartile ranges.

*** $P<0.001$; significantly different from the values obtained with samples of healthy cows.

coefficients were presented as measures of linear association for regression relationships. Significant differences of the slopes from zero were determined using a twotailed Student's $t$ test. $P<0.05$ was considered significant.

\section{RESULTS}

\section{Sample Characterization}

Cellular characteristics of milk samples recovered from healthy, and acute and chronic mastitis-affected cows are provided in Table 1. SCC in milk samples from healthy cows was always $<10^{5} \mathrm{cell} / \mathrm{s} / \mathrm{ml}$. Conversely, mastitis was accompanied by a drastic increase in SCC, which was always $>10^{7}$ in the acute form of the disease. Differential cell counts showed a significant increase in the percentage of neutrophils, associated with a significant decrease in the percentages of lymphocytes and macrophages, in milk samples from cows suffering from mastitis compared with healthy cows.

Milk samples from healthy cows contained no infectious agents (Table 2). On the contrary, pathogen bacteria were detected in milk of all mastitis-affected cows (Table 2). S. aureus was the main infectious agent present in milk samples from cows suffering from acute mastitis. S. aureus was also strongly associated with chronic mastitis (40\%). In this form of the disease, the incidence of $S$. agalactiae was high, reaching $25 \%$.

\section{NF- $\kappa$ B Activity in Milk Cells from Healthy and Mastitis-Affected Cows}

Active NF- $\kappa \mathrm{B}$ complexes were undetectable in milk cells from healthy cows, as determined by EMSAs (Figure 1A, lane 1). Conversely, protein extracts prepared from milk samples of acute mastitis-affected cows demonstrated a high NF- $\kappa \mathrm{B}$ activity (Figure 1A, lane 2). In milk cells from cows suffering from chronic mastitis, NF$\kappa \mathrm{B}$ activity varied from low to high (Figure 1A, lanes 4 and 3 , respectively). Two distinct NF- $\kappa$ B complexes were found in protein extracts obtained from milk cells of both acute and chronic mastitis-affected cows, a faster migrating complex and a slower migrating complex (Figure 1A). However, the slower complex was mainly observed in milk cells obtained from acute mastitis-affected cows (Figure 1A). DNA-binding competition experiments using 50 -fold excess of unlabeled wild-type and mutated palindromic $\kappa \mathrm{B}$ probes confirmed specificity of NF- $\kappa \mathrm{B}$ binding in cells obtained from mastits-affected cows (Figure 1B).

\section{Characterization of the NF- $\kappa$ B Complexes}

To characterize the two NF- $\kappa \mathrm{B}$ complexes found in milk cells from mastitis-affected cows, supershift experiments were performed with antibodies directed against the various members of the NF- $\kappa \mathrm{B}$ family, namely p65, p50, p52, c-Rel and Rel B (Figure 2). Preliminary western

Table 2. Bacteria isolated from milk samples of healthy, acute mastitis-affected and chronic mastitisaffected Holstein-Friesian cows.

\begin{tabular}{|c|c|c|c|c|c|c|c|c|c|}
\hline & \multicolumn{3}{|c|}{ Healthy $(\mathrm{n}=16)$} & \multicolumn{3}{|c|}{ Acute $(\mathrm{n}=6)$} & \multicolumn{3}{|c|}{ Chronic $(\mathrm{n}=20)$} \\
\hline & $\mathrm{n}$ & $\%$ & $\mathrm{cfu} / \mathrm{ml}$ & $\mathrm{n}$ & $\%$ & $\mathrm{cfu} / \mathrm{ml}$ & $\mathrm{n}$ & $\%$ & $\mathrm{cfu} / \mathrm{ml}$ \\
\hline Aerococcus viridans & 0 & 0 & 0 & 0 & 0 & 0 & 3 & 10 & $10000 \pm 4875$ \\
\hline Coagulase-negative Staphylococci & 0 & 0 & 0 & 0 & 0 & 0 & 2 & 10 & $4760 \pm 7520$ \\
\hline Lactococcus lactis & 0 & 0 & 0 & 0 & 0 & 0 & 1 & 5 & $>9999$ \\
\hline Leuconostoc spp. & 0 & 0 & 0 & 0 & 0 & 0 & 1 & 5 & $>9999$ \\
\hline Staphylococcus aureus & 0 & 0 & 0 & 3 & 50 & $2000 \pm 3780$ & 8 & 40 & $150 \pm 1500$ \\
\hline Streptococcus acidominis & 0 & 0 & 0 & 1 & 16.66 & $>9999$ & 0 & 0 & 0 \\
\hline Streptococcus agalactiae & 0 & 0 & 0 & 0 & 0 & 0 & 5 & 25 & $1600 \pm 4325$ \\
\hline Streptococcus bovis & 0 & 0 & 0 & 1 & 16.66 & $>9999$ & 2 & 10 & $>9999$ \\
\hline Streptococcus dysgalactiae & 0 & 0 & 0 & 1 & 16.66 & $>9999$ & 0 & 0 & 0 \\
\hline Streptococcus uberis & 0 & 0 & 0 & 0 & 0 & 0 & 3 & 15 & $>9999$ \\
\hline
\end{tabular}

Results are expressed as median \pm interquartile ranges. 
A

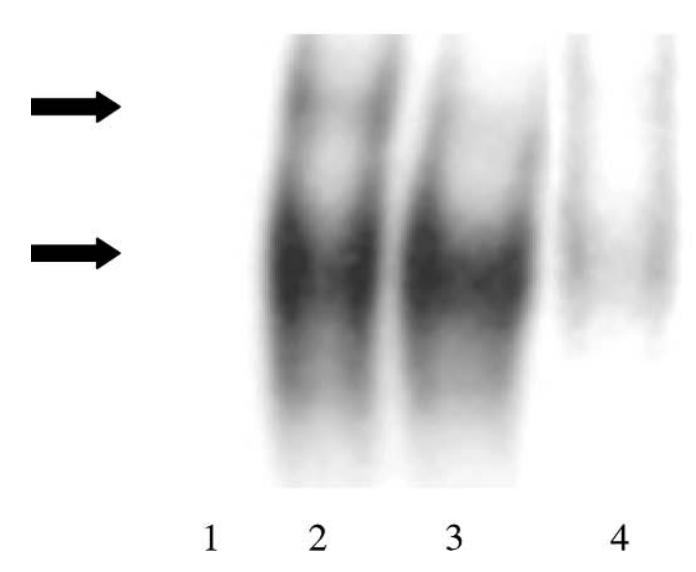

B

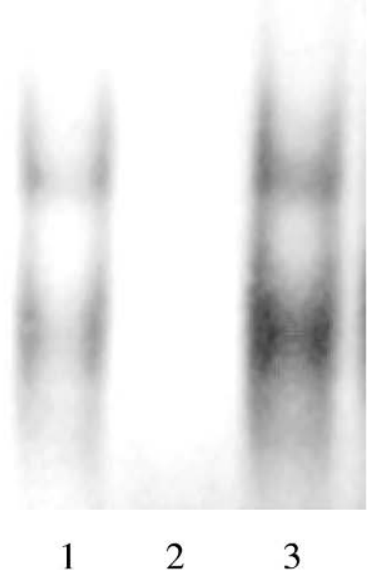

Figure 1. NF- $\kappa$ B activity in milk cells obtained from healthy, and acute and chronic mastitis-affected Holstein-Friesian cows. (A) Electrophoretic mobility shift assays were performed with protein extracts prepared from milk cells of one healthy cow (lane 1), one acute mastitis-affected cow (lane 2) and two chronic mastitis-affected cows (lanes 3 and 4 ). The solid arrows indicate specific NF- $\kappa \mathrm{B}$ complexes. (B) Specificity of NF- $\kappa \mathrm{B}$ complexes was confirmed in mastitis-affected cows by competition experiments using the same nuclear extracts incubated with a 50 -fold excess of unlabeled wild-type palindromic $\kappa \mathrm{B}$ probes (lane 2) and mutated palindromic $\kappa \mathrm{B}$ probes (lane 3). This experiment is representative of six similar experiments.

blot experiments clearly showed that all these antibodies are able to cross-react with the corresponding bovine $\mathrm{NF}-\kappa \mathrm{B}$ subunits (data not shown). Anti-p50 and antip65 antibodies, but not anti-p52, anti-c-Rel and antiRelB antibodies, were able to supershift the faster migrating complex (Figure 2, lanes 2 and 3), indicating that this complex is the classical p65/p50 heterodimer. Anti-p50, anti-p52, anti-c-Rel and anti-RelB antibodies did not react with the slower migrating complex (Figure 2, lanes 3-6), whereas anti-p65 weakly supershifted this complex (Figure 2, lane 2). Only p65 and c-Rel homodimers are markedly heavier than the p65/p50 heterodimer (Siebenlist et al., 1994). Because the slower migrating complex reacted weakly with anti-p65 antibodies, but not c-Rel antibodies, it may be hypothesized that this complex is a p65 homodimer.

\section{Relations Between the Level of NF- $\kappa$ B Activity and the Degree of Inflammation in the Mammary Gland}

$\mathrm{NF}-\kappa \mathrm{B}$ activity, SCC and neutrophil percentage varied from low to high in milk samples from chronic mastitisaffected cows, thus providing a unique opportunity to study the relationships between these variables. Accordingly, linear regressions were carried out to assess the relation between the level of NF- $\kappa \mathrm{B}$ activity, as assessed by photodensitometry, and SCC and the percentage of neutrophils in milk samples obtained from chronic mastitis-affected cows. These regression analyses showed that there is no significant correlation between these variables (Figure $3 \mathrm{~A}$ and $\mathrm{B}$ ).
We further examined the link between NF- $\kappa \mathrm{B}$ activity and the level of IL-8 and GM-CSF expression in milk cells. We have chosen to study these two cytokines because (1) they crucially depend on $\mathrm{NF}-\kappa \mathrm{B}$ activity for their expression (Schreck and Baeuerle, 1990; Kunsch and Rosen, 1993) and (2) they are critical for initiating and maintaining neutrophilic inflammation (Baggiolini et al., 1989; Coxon et al., 1999). Only small amounts of IL-8 and GM-CSF were revealed by immunoblot in protein extracts obtained from milk cells of healthy cows (Figure 4A, lane 1, and Figure 4B, lane 1, respectively). On the contrary, important amounts of these proteins were observed in cells from acute mastitis-affected cows (Figure 4A, lane 2, and Figure 4B, lane 2). In cells from chronic mastitis-affected cows, the expression level of IL-8 and GM-CSF varied from low to high (Figure 4A, lanes 4 and 3, and Figure 4B, lanes 4 and 3, respectively). Finally, regression analyses established that the level of IL-8 and GM-CSF expression in milk cells from chronic mastits-affected cows, as determined by photodensitometry, was highly $(P<0.01)$ correlated to the intensity of $\mathrm{NF}-\kappa \mathrm{B}$ activity (Figure $5 \mathrm{~A}$ and $\mathrm{B}$, respectively).

\section{DISCUSSION}

In the present study, we show for the first time that $\mathrm{NF}-\kappa \mathrm{B}$ activity is increased in milk cells from mastitisaffected cows, when compared to healthy cows. Because elevated NF- $\kappa \mathrm{B}$ activity is known to be responsible for increased expression of many genes encoding inflammatory proteins of relevance in mastitis, such 


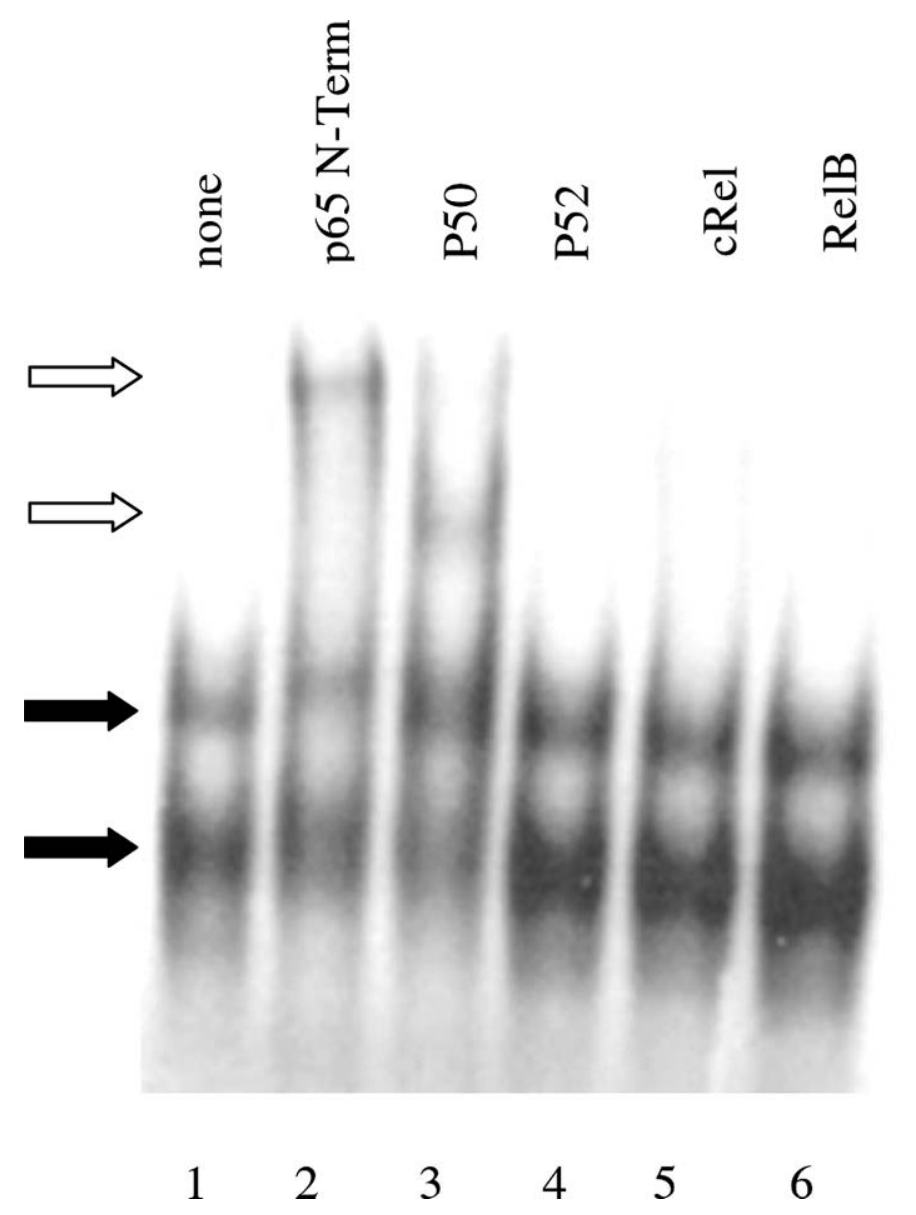

Figure 2. Characterization of specific active NF- $\kappa$ B complexes yielded by milk cells of mastitis-affected Holstein-Friesian cows. Supershift analysis was conducted with antibodies directed against p65 (lane 2), p50 (lane 3), p52 (lane 4), c-Rel (lane 5) and RelB (lane 6). The specific complexes are indicated by solid arrows. Supershift bands are indicated by open arrows. This experiment is representative of twelve similar experiments made with extracts from either acute or chronic mastitis-affected cows.

as adhesion molecules, chemokines and cytokines, our results suggest that $\mathrm{NF}-\kappa \mathrm{B}$ might play a role in mastitis pathogenesis.

Numerous bacteria may directly activate $\mathrm{NF}-\kappa \mathrm{B}$ in epithelial cells, which thereby triggers the inflammatory response (Münzenmaier et al., 1997; Nauman et al., 1997; Philpott et al., 2000). Bacteria may also induce $\mathrm{NF}-\kappa \mathrm{B}$ activity in residential macrophages through stimulation of Toll-like receptors (Zhang and Gosh, 2000), which have been recently identified as important mediators of the antibacterial response in mammalian cells (Brightbill et al., 1999). Moreover, bacteria-activated epithelial cells and macrophages release large amounts of proinflammatory cytokines, such as TNF- $\alpha$, which are themselves potentially able to activate NF- $\kappa \mathrm{B}$ in any cells present at the site of
A

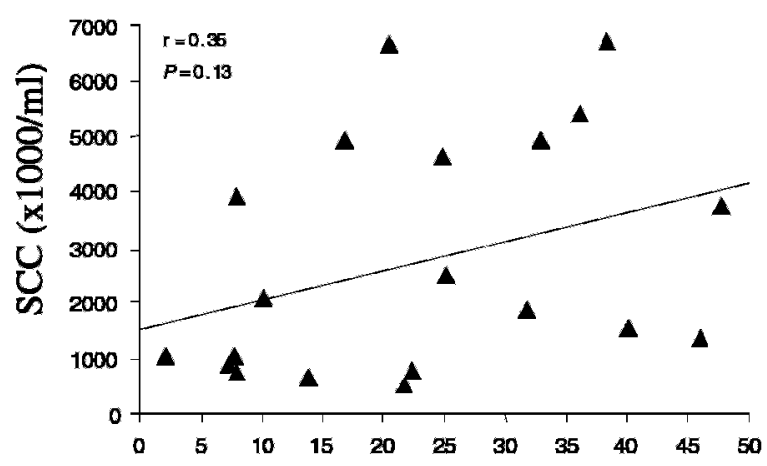

Level of NF- $\kappa B$ activity (relative values)

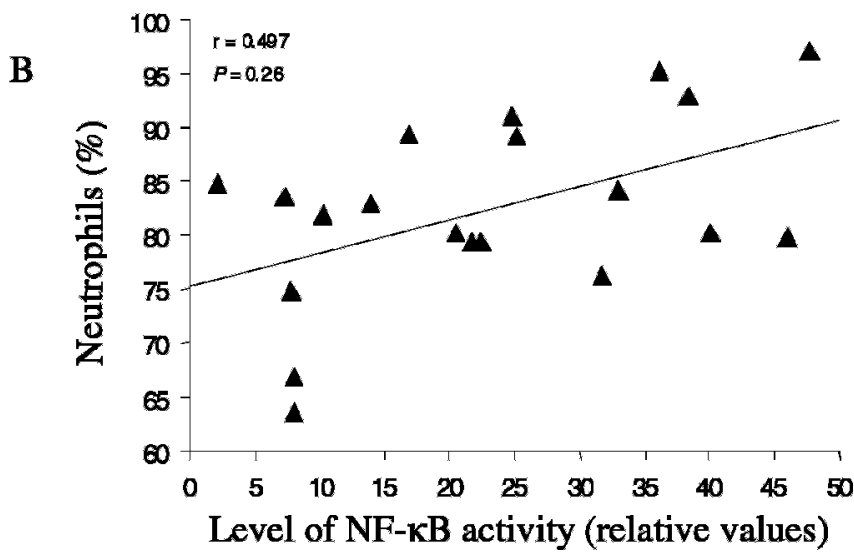

Figure 3. Relation between specific NF- $\kappa$ B activity displayed by milk cells, as determined by photodensitometry, and SCC (A) and the percentage of neutrophils (B) in chronic mastitis-affected HolsteinFriesian cows $(n=20)$. r, correlation coefficient.

infection, including the extravasated neutrophils (Agace et al., 1993; Naumann et al., 1997; Sharma et al., 1998). Accordingly, it may be assumed that the elevated NF- $\kappa \mathrm{B}$ activity detected in milk cells from

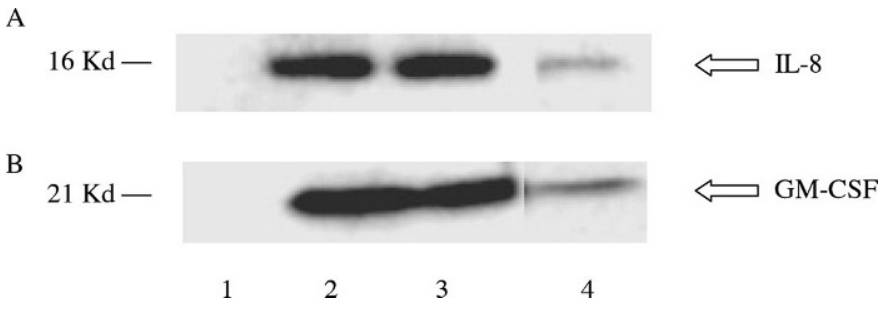

Figure 4. Representative IL- 8 and GM-CSF immunoblots performed with protein extracts from milk cells of healthy (lane 1) and acute (lane 2) and chronic (lanes 3 and 4) mastitis-affected HolsteinFriesian cows. Arrows indicate the position of the specific bands. These experiments are representative of six similar experiments. 
A

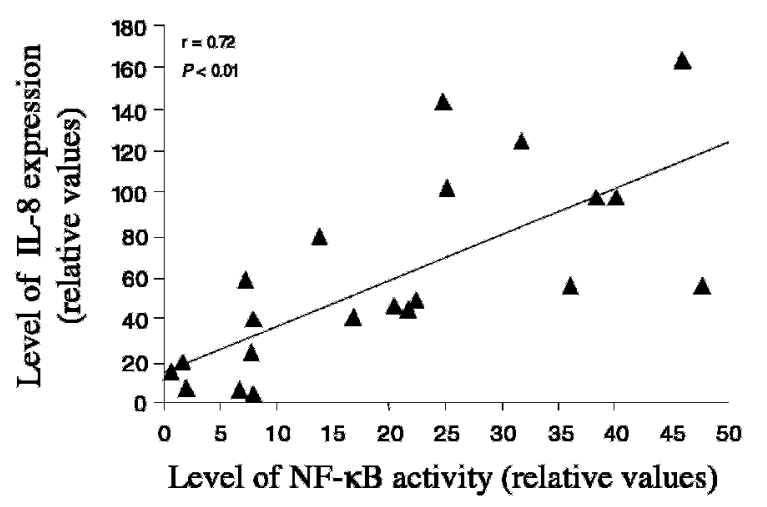

B

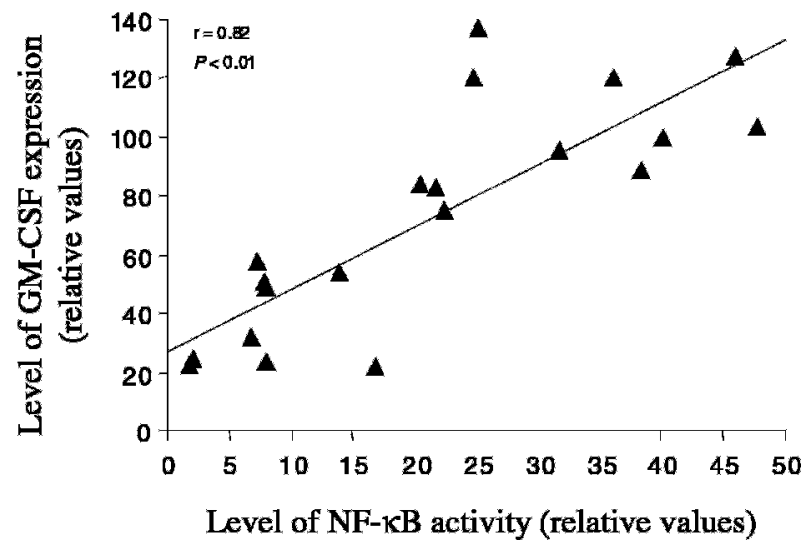

Figure 5. Relation between specific NF- $\kappa \mathrm{B}$ activity and the level of IL-8 (A) and GM-CSF (B) expression, as determined by photodensitometry, in milk cells obtained from chronic mastitis-affected Holstein-Friesian cows $(n=20)$. $r$, correlation coefficient.

mastitis-affected cows is due to direct and/or indirect stimulation of these cells by pathogenic bacteria, especially $S$. aureus, and $S$. agalactiae.

Protein extracts prepared from milk cells of mastitis-affected cows demonstrated two active NF- $\kappa \mathrm{B}$ complexes. The faster migrating complexes were classical p65-p50 heterodimers and were abundant in milk cells from both acute and chronic mastitis-affected cows. The retarded complexes were hypothetical p65 homodimers and were mainly found in cells of cows suffering from acute mastitis. Heterodimers p65-p50 are ubiquitous complexes that control the expression of numerous genes involved in inflammatory and immune responses (Gosh et al., 1998). On the contrary, p65 homodimers are uncommon complexes, which are thought to be crucial for the transcription of a restricted number of genes, including those encoding IL-8 and ICAM1 (Kunsch and Rosen, 1993; Ledebur and Parks, 1995). Recently, several studies established a role for p65 homodimers in chronic inflammation and in cellular responses to bacterial infection. p65 homodimers determine chronic airway inflammation and lung dysfunction in equine heaves (Sandersen et al., 2001). Yersinia enterolitica invasin protein triggers IL-8 production in epithelial cells by activating p65-p65 complexes (Schulte et al., 2000). Shigella flexneri, which causes inflammatory bowel disease, requires activation of p65 homodimers to induce IL-8 expression in HeLa cells (Philpott et al., 2000). Finally, H. pylori induces transcription of specific antimicrobial peptides through activation of p65-p65 complexes (Wada et al., 2001). All these observations indicate that p65 homodimers play a critical role in certain inflammatory and infectious diseases, especially those in which bacteria are involved. In bovine mastitis, hypothetical p65 homodimers were mainly observed in milk cells from acute mastitis-affected cows, suggesting that these complexes could regulate the expression of a subset of genes characteristic of acute mastitis.

The expression level of IL-8 and GM-CSF was drastically increased in milk cells of mastitis-affected cows, when compared to that found in milk cells from healthy cows. These findings are consistent with previous data from Barber and Yang (1998), who showed elevated IL-8 concentrations in mastitic secretions. IL- 8 is a potent neutrophil chemoattractant (Baggiolini et al., 1989), whereas GM-CSF delays neutrophil apoptosis (Coxon et al., 1999). Therefore, it is likely that these cytokines are crucial for triggering and maintaining the neutrophilic inflammation that characterizes mastitis. NF- $\kappa$ B plays a key role in transcriptional initiation of the genes encoding IL-8 and GM-CSF (Schreck and Baeuerle, 1990; Kunsch and Rosen, 1993). Accordingly, we postulated that the intensity of NF- $\kappa$ B activity in milk cells might determine the expression level of these cytokines. A highly significant correlation was found between the degree of NF- $\kappa \mathrm{B}$ activity and the level of IL-8 and GM-CSF expression in milk cells from chronic mastitis-affected cows, supporting our hypothesis. However, although these inflammatory variables were strongly correlated, no association was found between NF- $\kappa$ B activity and SCC and neutrophil percentage in milk samples of cows suffering from chronic mastitis. We have no definitive explanation for this discrepancy, but a hypothesis may be raised. It is logical to assume that NF- $\kappa$ B activation and IL- 8 and GMCSF expression are concomitant events that significantly precede neutrophil efflux, and that neutrophil efflux may reach a peak when NF- $\kappa \mathrm{B}$ is deactivated. Knowing that inflammatory signs fluctuate in milk samples during chronic infection, it is therefore possible that variations in NF- $\kappa \mathrm{B}$ activation, and IL-8 and GM-CSF expression, are not in phase with the varia- 
tions in neutrophil percentage and SCC. This hypothesis could explain why NF- $\kappa \mathrm{B}$ activity is highly correlated to the level of IL-8 and GM-CSF expression, but does not reflect instantaneous SCC and neutrophil percentage in milk samples from chronic mastitis-affected cows.

\section{CONCLUSIONS}

The present study shows for the first time that NF$\kappa \mathrm{B}$ activity is increased in milk cells from mastitisaffected cows. Because elevated NF- $\kappa \mathrm{B}$ activity is known to be associated with increased expression of numerous inflammatory genes, including those encoding IL-8 and GM-CSF, our results suggest that NF$\kappa \mathrm{B}$ plays a role in mastitis pathogenesis. Future studies are needed to clarify this role.

\section{ACKNOWLEDGMENTS}

The authors thank M. Motkin, E. Jacquemin, I. Sbai, and M. Leblond for technical and secretarial assistance. The Laboratory of the Milk Committee is thanked for the cell count performance. Authors are grateful to Prof. Dr. C. Burvenich, Dr. D. Hoeben, Dr. $\mathrm{K}$. Vlaminck, and F. Vangroenweghe for advice. This work was partly supported by Janssen Animal Health (Belgium), and the Ministère des Classes Moyennes et de l'Agriculture-Administration Recherche et Développement (Belgium). D.B. is a fellow from the Fonds pour la Formation à la Recherche dans l'Industrie et l'Agriculture (FRIA, Belgium). F.B. is a Research Assistant at the National Fund for Scientific Research (FNRS, Belgium).

\section{REFERENCES}

Agace, W., S. Hedges, U. Andersson, J. Andersson, M. Ceska, and C. Svanborg. 1993. Selective cytokine production by epithelial cells following exposure to Escherichia coli. Infect. Immun. 61:602-609.

Al-Shami, A., W. Mahanna, and P. H. Naccache. 1998. Granulocytemacrophage colony-stimulating factor-activated signaling pathways in human neutrophils. Selective activation of Jak2, Stat3, and Stat5b. J. Biol. Chem. 273:1058-1063.

Baggiolini, M., A. Walz, and S. L. Kunkel. 1989. Neutrophil-activating peptide-1/interleukin 8 , a novel cytokine that activates neutrophils. J. Clin. Invest. 84:1045-1049.

Barber, M. R., and T. J. Yang. 1998. Chemotactic activities in nonmastitic and mastitic mammary secretions: Presence of interleukin-8 in mastitic but not nonmastitic secretions. Clin. Diagn. Lab. Immunol. 5:82-86.

Beg, A. A., T. S. Finco, P. V. Nantermet, and A. S. J. Baldwin. 1993. Tumor necrosis factor and interleukin-1 lead to phosphorylation and loss of I kappa B alpha: A mechanism for NF-kappa B activation. Mol. Cell. Biol. 13:3301-3310.

Brightbill, H. D., D. H. Libraty, S. R. Krutzik, R. B. Yang, J. T. Belisle, J. R. Bleharski, M. Maitland, M. V. Norgard, S. E. Plevy, S. T. Smale, P. J. Brennan, B. R. Bloom, P. J. Godowski, and R. L. Modlin. 1999. Host defense mechanisms triggered by micro- bial lipoproteins through toll-like receptors. Science 285:732736.

Burvenich, C., M. J. Paape, A. W. Hill, A. J. Guidry, R. H. Miller, R. Heyneman, and W. D. Kremer, A. Brand. 1994. Role of the neutrophil leucocyte in the local and systemic reactions during experimentally induced E. coli mastitis in cows immediately after calving. Vet. Q. 16:45-50.

Coxon, A., T. Tang, and T. N. Mayadas. 1999. Cytokine-activated endothelial cells delay neutrophil apoptosis in vitro and in vivo. A role for granulocyte/macrophage colony-stimulating factor. J. Exp. Med. 190:923-934.

DeGraves, F. J., and J. Fetrow. 1993. Economics of mastitis and mastitis control. Vet. Clin. North Am. Food Anim. Pract. 9:421-434.

Ghosh, S., M. J. May, and E. B. Kopp. 1998. NF-kappa B and Rel proteins: Evolutionarily conserved mediators of immune responses. Annu. Rev. Immunol. 16:225-260.

Jain, N. C. 1979. Common mammary pathogens and factors in infection and mastitis. J. Dairy Sci. 62:128-134.

Kunsch, C., and C. A. Rosen. 1993. NF-kappa B subunit-specific regulation of the interleukin-8 promoter. Mol. Cell. Biol. 13:6137-6146.

Ledebur, H. C., and T. P. Parks. 1995. Transcriptional regulation of the intercellular adhesion molecule- 1 gene by inflammatory cytokines in human endothelial cells. Essential roles of a variant NF-kappa B site and p65 homodimers. J. Biol. Chem. 270:933-943.

Münzenmaier, A., C. Lange, E. Glocker, A. Covacci, A. Moran, S. Bereswill, P. A. Baeuerle, M. Kist, and H. L. Pahl. 1997. A secreted/shed product of Helicobacter pylori activates transcription factor nuclear factor-kappa. Br. J. Immunol. 159:61406147.

Naumann, M., S. Wessler, C. Bartsch, B. Wieland, and T. F. Meyer. 1997. Neisseria gonorrhoeae epithelial cell interaction leads to the activation of the transcription factors nuclear factor kappaB and activator protein 1 and the induction of inflammatory cytokines. J. Exp. Med. 186:247-258.

Paape, M. J., W. P. Wergin, A. J. Guidry, and R. E. Pearson. 1979. Leukocytes-second line of defense against invading mastitis pathogens. J. Dairy Sci. 62:135-153.

Pahl, H. L. 1999. Activators and target genes of Rel/NF-kappaB transcription factors. Oncogene. 18:6853-6866.

Philpott, D. J., S. Yamaoka, A. Israel, and P. J. Sansonetti. 2000. Invasive Shigella flexneri activates NF-kappa B through a lipopolysaccharide-dependent innate intracellular response and leads to IL-8 expression in epithelial cells. J. Immunol. 165:903-914.

Riollet, C., P. Rainard, and B. Poutrel. 2001. Cell subpopulations and cytokine expression in cow milk in response to chronic Staphylococcus aureus infection. J. Dairy Sci. 84:1077-1084.

Sandersen, C., F. Bureau, R. Turlej, L. Fievez, S. Dogne, N. Kirschvink, and P. Lekeux. 2001. p65 Homodimer activity in distal airway cells determines lung dysfunction in equine heaves. Vet. Immunol. Immunopathol. 80:315-326.

Schulte, R., G. A. Grassl, S. Preger, S. Fessele, C. A. Jacobi, M. Schaller, P. J. Nelson, and I. B. Autenrieth. 2000. Yersinia enterocolitica invasin protein triggers IL-8 production in epithelial cells via activation of Rel p65-p65 homodimers. FASEB J. 14:1471-1484.

Schalm, O. W., and J. Lasmanis. 1968. The leukocytes: Origin and function in mastitis. J. Am. Vet. Med. Assoc. 153:1688-1694.

Schreck, R., P. A. Baeuerle. 1990. NF-kappa B as inducible transcriptional activator of the granulocyte-macrophage colonystimulating factor gene. Mol. Cell. Biol. 10:1281-1286.

Sharma, S. A., M. K. Tummuru, M. J. Blaser, and L. D. Kerr. 1998. Activation of IL-8 gene expression by Helicobacter pylori is regulated by transcription factor nuclear factor-kappa B in gastric epithelial cells. J. Immunol. 160:2401-2407.

Shuster, D. E., M. E. J. Kehrli, and M. G. Stevens. 1993. Cytokine production during endotoxin-induced mastitis in lactating dairy cows. Am. J. Vet. Res. 54:80-85. 
Siebenlist, U., G. Franzoso, and K. Brown. 1994. Structure, regulation and function of NF-kappa B. Annu. Rev. Cell Biol. 10:405-455.

Vangroenweghe, F., H. Dosogne, J. Mehrzad, and C. Burvenich. 2001. Effect of milk sampling techniques on milk composition, bacterial contamination, viability and functions of resident cells in milk. Vet. Res. 32:565-579.

Wada, A., K. Ogushi, T. Kimura, H. Hojo, N. Mori, S. Suzuki, A. Kumatori, M. Se, Y. Nakahara, M. Nakamura, J. Moss, and T. Hirayama. 2001. Helicobacter pylori-mediated transcriptional regulation of the human beta-defensin 2 gene requires NF-kappaB. Cell. Microbiol. 3:115-123.

Watts, J. L. 1988. Etiological agents of bovine mastitis. Vet. Microbiol. 16:41-66.

Whiteside, S. T., J. C. Epinat, N. R. Rice, and A. Israel. 1997. I kappa B epsilon, a novel member of the I kappa B family, controls RelA and cRel NF-kappa B activity. EMBO J. 16:1413-1426.

Zhang, G., and S. Ghosh. 2000. Molecular mechanisms of NF-kap$\mathrm{paB}$ activation induced by bacterial lipopolysaccharide through Toll-like receptors. J. Endotoxin Res. 6:453-457. 